\title{
Manifest niepoprawności
}

\section{1}

Nauka i sztuka mają ze sobą wiele wspólnego. Obydwie coś tworzą. Jednak tworzą też: inżynieria, rolnictwo, pedagogia, lecznictwo itd. Z pewnością bliżej im do wytwarzania. W czym tkwi różnica? Cele dziedzin praktycznych leżą poza ich własnym obszarem - w satysfakcji z życia innych ludzi. Sztuka i nauka nie poszukują zastosowań utylitarnych. Służą sobie samym, ich wartość jest immanentna. Zawiera się we własnym paradygmacie, a satysfakcje czy porażki, czyli cała sfera emocjonalno-motywacyjna, również są immanentne. Całe szczęście, że naukowcy są także konsumentami i użytkownikami dóbr doczesnych, bo inaczej staliby się niewidzialni. Artyści przeciwnie - chcą się pokazać. Dlatego pokrewieństwo nauki i sztuki musi być wydobyte z gęstwiny różnic, instytucjonalnych zasłon, a co najważniejsze - z pozorów fałszywych tożsamości. Powtórzmy: nauka i sztuka stużą sobie samym.

\section{2}

Nauka i sztuka stawiają pytania. Inne dziedziny też stawiają, ale one pytają, jak coś zrobić, jak sprawić, jak coś wywołać. Na przykład: „jak zmienić wklęste na wypukłe?", bo ludzkość potrzebuje wypukłych. Skąd jednak wiedzą, że ludzkość tego potrzebuje. Po pierwsze - bo wypukłe już są, ale jest ich za mało i nie starcza dla wszystkich. Wniosek: trzeba zwiększyć wydajność. To powszechne prawo konsumpcji - wiemy, czego chcemy, ale jeszcze tego nie mamy. Chcemy więcej rzeczy. A potem - lepszych rzeczy. Lepsze rzeczy mają tylko lepsi, a my chcemy tego, co oni już mają, dlatego musi być tego więcej. I tak jakość przechodzi w ilość. Era industrialna wysunęła na pierwsze miejsce żądanie wynalazczości, z nauki czyniąc głównie suport w pogoni dobrobytu. Nauka i sztuka zdobędą środki, jeśli dowiodą, że ich jakość przechodzi w ilość! 
W rozbudzonych oczekiwaniach społeczeństw nie ma powszechnego pożądania ani nauki, ani sztuki. Dla ludności nie jest jasne, jaki może być cel takiej aktywności. W powszechnym mniemaniu cel równa się sensowi. Skąd tedy twórcy czerpią napęd i satysfakcję, skoro społeczeństwa niczego od nich nie oczekują? Synonimiczne rozumienie celu i sensu jest fosą, która oddziela ludzi tworzących od całej reszty. Twórcy zamknięci są w twierdzy i zajmuja się gra szklanych paciorków, grą niepojętą dla oblężniczej armii, której sensem istnienia jest ograbienie twierdzy.

Nauki i sztuki nie tworzy się w jakimś celu, ale z powodu i to stanowi o ich sensie. Jest zarazem dowodem prawdziwej tożsamość tych dwu dziedzin. Każdego naukowego czy artystycznego oszusta poznacie po tym, że rozprawia o celach. Zapytajcie wśród znajomych, dlaczego robią naukę lub sztukę. Większość, nie wiedząc, że się pogrąża, odpowie, że chcą coś zmajstrować dla innych albo wywrzeć na nich jakieś wrażenie. Pytacie ich o powód, a ich odpowiedź mówi o celu. Himalaiści zdobywają góry, bo one są. Nie zdobywają ich po coś, ale dlatego, że tak chcą, że aż muszą.

Środowisko nominalnych twórców, czyli uczonych i artystów, pełne jest symulantów dostarczających produkty naukopodobne lub sztukopodobne. Jest tak dlatego, że na uniwersytetach, podobnie jak w podstawówkach, zwalcza się myślących inaczej. Człowiek ma więc do wyboru: albo żyć z uniwersytetu, albo żyć z własnych fanaberii. Co radzilibyście wybrać?

Najbardziej znanym mi opresyjnym dla twórczości środowiskiem są akademie sztuki. Jako że pseudoartyści żywią się sławą, dlatego postawy twórcze innych są dla nich śmiertelnym zagrożeniem, bo przekłuwają nadęte balony.

Zarówno w nauce, jak i sztuce nie chodzi o to, aby coś powiedzieć, czy w inny sposób wyrazić. Tu chodzi o to, aby się czegoś dowiedzieć. Motorem działania nie jest spektakularny cel, lecz obsesja poznania tego, co leży poza umysłowym widnokręgiem.

Dwóch geniuszy elektryczności - Edison i Tesla - to dwie różne postawy. Edison to typ wynalazcy, którego interesowały głównie zyski ze sprzedaży swoich licznych technicznych patentów. Tesla to typ badacza, którego obsesją była natura prądu przemiennego.

Edison zbudował żarówkę, ale przecież nie on odkrył żarzenie wywołane oporem prądu. Jego światło elektryczne zmieniło świat, ale w wiedzy naukowej nie zmieniło wiele.

Tesla badał zagadkę falowego przesyłania prądu i przekształcania go w inny rodzaj energii. Budowane do tego różne naukowe przyrządy okazały się potem 
silnikiem elektrycznym, prądnicą, baterią słoneczną, świetlówką, radiem i łukiem elektrycznym. Nie miał celu, miał raczej obsesyjną pasję poznawania tego, czego inni nie widzą, bo nauka i sztuka nie mają celu, istnieją z powodu.

Epoka postindustrialna przyniosła nową ideę wynalazczości. To komputer, uniwersalna metamaszyna, umiejąca zarządzać wszystkimi narzędziami wytwórczymi. Projektowanie świata rzeczy przeniosło się na arenę psycho- i socjotechniczną. To była poważna zmiana paradygmatu. Pytanie zostało przeredagowane z: „czego ludzie potrzebują?” na: „czego by jeszcze zapragnęli, gdyby to było?”. Z pewnością nowym geniuszem okazał się nie wynalazca majsterkowicz, ale prorok widzący przyszłość - Steve Jobs. Nie nasłuchiwat, czego ludzie potrzebują, ale objawiat im drogę do ziemskiego zbawienia, a na to zawsze jest popyt. Nie był w tym pierwszy. Sam często przywoływał taką wypowiedź Henry’ego Forda: „gdybym na początku swojej kariery zapytat klientów, czego potrzebują, wszyscy byliby zgodni: chcemy szybszych koni”.

Wyznanie Forda odnosiło się do maszyny, która zastąpiła furę. Jobs to samo rozumowanie odnióst do metamaszyny, czyli komputera. Wniosek był prosty: nie pytajmy ludzi, czego chcą, ale dajmy im coś, co ich zaskoczy i zachwyci.

Jobs nie wymyślit ani komputera, ani systemu operacyjnego. Niczego nie wynalazt, ale miał absurdalnq wizję powszechnej dostępności metamaszyny, podobnie jak Tesla, który miał wizję powszechnego użytku energii elektrycznej. Obydwaj potrafili wyobrazić sobie inny świat, inaczej działający i ludzi myślących zupełnie inaczej.

Jobs ogłosit, że zasada powszechnego twórczego działania zawiera się w haśle „myśl inaczej” i powierzył tym słowom patronat nad swoją firmą i całym światem. Jednak sens tych słów był odmienny niż u Forda. Nie idzie o to, abyś myślał inaczej niż inni, ale byś myślał inaczej, niż sam myślisz. Ciągle inaczej, a najlepsze samo się pokaże. W ten sposób Jobs zaproponował definitywny rozwód z prawdą. Dla tego pojęcia nie ma już miejsca w świecie zarządzanym przez big data. Nie ma już prawdy, nie ma nawet racji, jest tylko wynik i jego prawdopodobieństwo. A prawda? Prawda ze swej istoty jest niepoprawialna. Jednak wynik zawsze możesz poprawić, tylko myśl inaczej. 
Z myśleniem inaczej największe kłopoty mają specjaliści. Musimy jednak zwrócić się do inżynierów, aby zbudowali coś, o czym nie mają pojęcia. Dlatego ich cel działania sformułujemy ich językiem i zapłacimy im za pracę.

Przełomów nie robią specjaliści. Mogą oni niemało poprawić, ale nie zostawiajcie ich samych w pokoju, bo gdy wrócicie, odkryjecie, że rozwiązują swoje problemy, a nie wasze. Rozwiązują swój czysto ludzki problem zatrudnienia. Technokraci zawsze będą wam mówić o problemach technicznych. Nie dajcie się nabrać. Nie ma problemów technicznych. Problemy są ludzkie w wymiarze psychologicznym i społecznym. Techniczne są zadania, a nie problemy. Tu znów nastąpiła, delikatnie mówiąc, inwersja znaczeń. Zamazane zostało rozróżnienie na zadania i problemy, podobnie jak na cel i powód. Należy więc jasno powiedzieć, że zadanie jest pragmatyczną drogą do rozwiązania ludzkiego problemu. Jest sposobem jego rozwiązania. Jednak wielokrotne stosowanie podobnego rozwiązania powoduje, że narzędzia zaczynają definiować sam problem. Na przykład twierdzenie, że głód w Afryce zostanie pokonany, gdy wysyłać będziemy dwadzieścia osiem razy więcej samolotów z żywnością. Tak więc przyczyną głodu jest brak samolotów. Wniosek jest logicznie uprawniony. Klasyka myślenia indukcyjnego: najpierw przypadek, dalej wynik, na końcu reguła.

Przychodzi student do uczonego i mówi: „Mam taki problem, nie wiem, ile jest 7 + 9”. Uczony odpowiada: „A ja wiem i nie mam problemu. Ty cierpisz, a ja nie”.

Nie cierpi też matematyka, bo nie umie cierpieć.

Teraz odpowiedzmy, czy problem jest matematyczny, czy ludzki.

Jakże często w nauce i sztuce zadania uchodzą za problemy, a problemy pozostają niewidzialne. Czym są rozprawy doktorskie i habilitacyjne, jeśli nie indeksem dowodów, że badacz dobrze włada narzędziami badawczymi. Umie rozwiązywać zadania. Uczciwie jednak dodam, że niektóre rozprawy są inne.

Nauce specjalistycznej brakuje często zrozumienia, a także narzędzi diagnozowania problemów. Żyjemy w technokratycznym terrorze gotowych zadań, bez zadawania pytania „dlaczego?".

Świat wmawia nam, że jedynym ważnym pytaniem jest: „po co?”.

Wierzcie mi, pytania o problemy należą do kategorii pytań humanistycznych. Widać już pewne śladowe oznaki wypracowywania nowych sensów humanistyki. Nie przebiją się łatwo, gdyż warunkiem sine qua non będzie ogłoszenie, że humanistyka w żadnym wydaniu nie jest nauką, ale mimo to jest wiedzą twórczą. Nie chodzi o unicestwienie humanistyki, ale o istotną korektę jej kursu. Obecnie w starciu z teraźniejszością próbuje swych sił brednia pod nazwą posthumanistyka. 
(Gdy pisałem ten tekst, mój komputer ostrzegł mnie, że pojęcia posthumanistyka nie ma. Dzięki ci mój Macu!)

Ciekawe, że posthumanistyka spełnia wszystkie postulaty wiedzy stosowanej, czyli celowości. Dlatego nie diagnozuje problemów, tylko doskonali narzędzia.

Wymówką jest to, że nie ma prawdy. To przecież nie znaczy, że nie ma problemów.

Pewien nieżyjący już artysta konceptualny u schyłku życia powiedział do mnie takie zdanie: „Całe życie poświęciłem na przecieranie okularów i nie zdążyłem zobaczyć, co przez nie widać". Uważał, że patrzył wyłącznie na szkiełka, a nie przez szkiełka. Wydaje się, że humanistyka wpadła w podobną pułapkę i nie przygląda się światu, ale swojemu manicure'owi.

Powtórzmy: problem otwiera się pytaniem „dlaczego człowiek coś...”/„dlaczego ludzie coś...?". Nie, po co, ale dlaczego.

Aż korci, by odpowiedzieć: „bo chcą tego i owego”.

Wiedza ekspercka obejmuje najważniejsze zasoby kulturowe i cywilizacyjne, ale twórczość polega na transgresji wiedzy specjalistycznej. Coś, co wydaje się ustalone, zostaje przekroczone. Chcąc tworzyć, musimy być na topie powszechnej wiedzy eksperckiej, która jest ostatnim szczeblem drabiny, a my, stojąc na nim, musimy jeszcze troszkę podskoczyć. Rola specjalistów jest poważna. To oni gwarantują najwyższą jakość status quo, ale nie zapraszajmy ich do podskoków na szczycie drabiny. Spróbujmy ich wiedzę wykorzystać na ziemi, nim wejdziemy na drabinę. Czołowy amerykański pisarz fantastyki naukowej Robert Heinlein daje taką radę: „Wsłuchuj się zawsze w głos ekspertów. Powiedzą ci, co jest niemożliwe i powiedzą dlaczego. A potem po prostu zrób to”. To bardzo bystre spostrzeżenie - „Powiedzą ci, co jest niemożliwe i dlaczego”. Sądzę, że w tej niemożliwości jest ważna podpowiedź, omal wskazanie, którędy masz się przeprawić na drugą stronę lustra. Ty musisz wymyślić, jak to zrobisz. A jak to zrobisz, zobaczysz inne wymiary świata. Dlaczego nie mieliby zrobić tego samego specjaliści? Ponieważ ich nie interesuje, co jest za horyzontem. Wolą grać na swoim boisku, gdzie się na ogół wygrywa. Ten, kto lubi wycieczki za widnokrąg, jest po prostu wariatem. Mark Twain tak to wyraził: „Człowiek z nowymi pomysłami jest wariatem, dopóki nie odniesie sukcesu”.

Nie każdy jednak potrafi być wariatem. Twórczość jest obciążona ryzykiem zmarnowania życia. Dlatego budzi lęk.

Znów posłuchajmy starego Henry'ego Forda, który tak odróżniał ludzi z odwagą i pasją od całej reszty: „Jeśli sądzisz, że potrafisz, to masz rację - potrafisz. Jeśli 
zaś sądzisz, że nie potrafisz - również masz rację - nie potrafisz". Wątpliwe jest, czy wszyscy, którzy sądzą, że potrafią, potrafią naprawdę, ale tylko ci, którzy tak sądzą, próbują. Ci, co wiedzą, że nie potrafią, nawet nie próbują.

Poza odwagą i pasją poznawczą kandydat na twórcę musi mieć pewne walory intelektualne. Amerykański psycholog Robert J. Sternberg widzi trzy składowe twórczego umysłu. Są nimi: inteligencja pragmatyczna, analityczna i kreatywna. Trzeba mieć to wszystko, ale ilu jest takich ludzi. W populacji przeważają ludzie lewomózgowi. To ta półkula zajmuje się analizowaniem, systematyzowaniem, czytaniem symboli, widzeniem przedmiotowym, tworzeniem teorii dedukcyjnych, abstrahowaniem. Ten typ był kiedyś bardziej sapiens i w pierwotnych społecznościach miat największe szanse przetrwania. Dlatego lewomózgowych jest najwięcej. Do jakiej chwały wyniesiona została ich prawa ręka, a jak kiepski był los mańkuta. Mówiąc o kimś: „to jest prawa ręka prezesa”, myślimy, że „to jest prawdziwa głowa prezesa”. Dodajmy - lewostronna głowa.

Głowa prawostronna to głowa mańkuta. To ona jest maszynką emocji, spontaniczności, kreatywności, widzenia zjawiskowego, syntetycznego ujmowania istoty i wyciskania esencji. Jej systemem operacyjnym jest abdukcja.

Pragmatycy przeważnie pracują obiema półkulami, mimo że mają jakąś wrodzoną lateralizację. Są dobrzy we wdrożeniach, gdzie równie ważne są: zmyst praktyczny, pomysłowość i trochę spekulacji. Taką grupą w Polsce są rolnicy. Mieszkam od dwudziestu lat na wsi i nie mogę wyjść ze zdumienia, jacy to sprytni i pomysłowi ludzie. Wniosek mam taki: jeśli człowiek musi sam sobie wszystko zrobić, rozwija obydwie półkule. Ci ludzie widzą problemy i je zadaniowo rozwiązują, indukcyjnie, ale mądrze. Problem w tym, że rozwiązują problem swój, nie troszcząc się o ludzkość.

Kto więc jest dobrym kandydatem na twórcę?

Społeczny margines. Mniej niż jeden procent populacji.

Koniec tej części jest taki: nie ma pociechy dla niezdolnych.

PS. Dlatego niezdolni nie lubią zdolnych.

Komputerowa metafora ludzkiego mózgu nie rozstrzyga kwestii systemu operacyjnego. Przyjdzie nam na to poczekać. Wspomnieliśmy wcześniej, że jednostki kreatywne myślą abdukcyjnie. To znaczy jak? Czym jest takie myślenie? Klasyczny podział na dedukcję i indukcję podważył prawie sto lat temu Charles Peirce, wprowadzając do logiki procedurę pośrednią. Właśnie ta procedura była pierwszą 
rezygnacją z kategorii prawdy na rzecz prawdopodobieństwa. Abdukcja to po polsku porwanie, uprowadzenie, a po angielsku nawet kidnaping. Brzmi tajemniczo. Wróćmy więc do przykładu studenta, który nie wie i cierpi, profesor zaś nie cierpi, bo wie. Abdukcyjny rozkład tej sytuacji byłby taki:

Reguta: Profesor wie, student nie.

Wynik: Student cierpi, profesor nie.

Przypadek: Student cierpi, bo nie wie.

Reguła „Profesor wie, student nie” może prowadzić do wyniku, że niewiedza może, ale nie musi prowadzić do cierpienia. I w tym przypadku to student cierpi, ale z własnej winy. Czy profesor też może cierpieć? Nie może, gdyż wszystko wie, lub może, ale z innego powodu, na przykład bo reprezentacja kraju przegrała mecz.

Mamy tu dwie różnice pomiędzy profesorem a studentem. Jeden wie, drugi nie, oraz jeden cierpi, drugi nie. Pierwsza różnica jest lepszym materiałem na zbudowanie reguły, gdyż słowa profesor i student mają więcej wspólnego z wiedzą niż z cierpieniem. Kolejne pytanie poznawcze jest takie: „kto jest lepszym kandydatem na cierpiącego: wiedzący profesor czy niewiedzący student?". Zapewne student, choć i profesor może cierpieć dlatego, że student nie wie. I tu wyłania się prawdziwie ludzki problem, nawet dramat, na który nie ma gotowej instrukcji. Tu trzeba coś wymyślić, to znaczy rozkminić cały system akademicki.

To, co w tej logice jest istotne, to jej probabilistyczna formuła. Po słowach było i jest używa ona wyrażenia być może. Życie pokazało, że to podejście, szukające nie prawdy, ale prawdopodobieństwa, przyniosło urodzaj twórczych teorii i nowatorskich wynalazków. Być może tak jest.

\section{8}

Jednym w wątpliwych mitów jest interdyscyplinarność. Czym ona jest, że zrobiła karierę w nauce i sztuce? Pomiędzy dyscyplinami z pewnością można znaleźć wiele ciekawego. Zapytajmy jednak, czym są dyscypliny, zanim wypuścimy się poza ich autonomiczne terytoria. Podam przykład z zakresu sztuk wizualnych. Sztuki te podzielono na trzy dyscypliny: malarstwo, grafikę i rzeźbę. Jesteś albo tym, albo tym, albo tym. Dlaczego?

Takie też są kierunki studiów. Interdyscyplinarność zaś polega na wytwarzaniu tak zwanych dzieł plastycznych, które są częściowo malarskie, częściowo rzeźbiarskie czy graficzne. Kombinacji i procentowego udziału poszczególnych dyscyplin jest wiele. Jeśli na poważnie coś ma być dyscypliną poznania artystycznego czy naukowego, to ta dyscyplina powinna mieć jakąś wykładnię własnej odrębności. 
Zapytałem kiedyś grafika, profesora ASP, czy może mi wytłumaczyć, dlaczego robi więcej niż jedną odbitkę graficzną. Zaskoczony pytaniem odpowiedział, że na tym polega grafika. Zapytałem, czy liczba odbitek jest ważnym zagadnieniem w jego twórczości. Pozwolicie, że nie będę już kończył. Malarze malują obrazy seriami lub tak zwanymi zestawami, szczególnie gdy robią przewody akademickie. Kiedyś, podczas takiej prezentacji, zapytałem kandydata, czy po namalowaniu drugiego i kolejnego obrazu dowiedział się czegoś nowego, czego nie wiedział po namalowaniu uprzedniego. Zrobiło się nieprzyjemnie, a dziekan powiedział, że przedmiotem oceny jest cały zestaw. Poprosiłem więc, aby kandydat wskazał powód, dla którego każdy z obrazów tłumaczy się jedynie jako część większej całości. Zrobiło się jeszcze bardziej nieprzyjemnie. W akademickim środowisku artystycznym nie zadaję już pytań o interdyscyplinarność, kiedy tak wygląda wykładnia dyscyplinarności.

Terminu interdyscyplinarność używa się też na określenie mieszanych zespołów specjalistów, zajmujących się złożonymi zagadnieniami. Udziału wielu specjalistów do wykonywania specyficznych zadań wymaga na przykład operacja serca. W tym przypadku każdy zna się na swojej robocie i każdy za nią odpowiada. To nie jest żadna nowość. W prehistorycznej rodzinie chłop szedł na polowanie, a kobieta robiła przy kuchni, wychowywanie dzieci było interdyscyplinarne.

Interdyscyplinarność może oznaczać: 1) jeszcze węższą, szczelinową specjalizację, 2) połączenie ze sobą różnych technologii albo 3) wspótpracę specjalistów z pokrewnych dziedzin. Nie potrafię znaleźć w tym żadnego twórczego pomysłu innego niż podział pracy w rodzinie.

Interdyscyplinarność posługuje się językiem zadaniowym, narzędziowym, technicznym. Nie diagnozuje jednak problemów, gdyż nie tworzy własnego metajęzyka, a jedynie zwiększa zasoby danych. Profesor informatyki Andrew Sage zauważył, że efektywne rozwiązywanie złożonych problemów możliwe jest tylko z użyciem metasystemowej komunikacji, czyli metajęzyka wspólnego wielu systemom. Określit to jako poziom transdyscyplinarny, który zarządza poziomem interdyscyplinarnym i dyscyplinarnym.

Transdyscyplinarność służy formułowaniu problemów - nie w żargonie specjalistycznym, ale w języku powszechnie zrozumiałym. Specjaliści zatrudnieni w mieszanych zespołach muszą rozumieć ogólny sens wspólnej pracy. Tylko wówczas mogą dostrzec te elementy własnej dziedziny, które mogą być pomocne w rozwiązaniu centralnego problemu, nad którym pracuje zespół. Połączenie specjalistów $w$ transdyscyplinarnym systemie systemów daje efekt synergii, a nie prostej sumy składowych zadań. Nie jest więc tylko podziałem pracy, ale konstruktem transgresyjnym. Transdyscyplinarność służy formułowaniu problemów. 
Pamięć i wyobraźnia. Psychologia rozróżnia dwa rodzaje wyobraźni. Pierwszy to odtwarzanie, czyli wyobraź sobie to, co już widziałeś, przypomnij sobie. Jest to rekonstrukcja na zawołanie określonych zasobów pamięciowych (dobrze opisat to Gibson). Drugi to przekształcanie - wyobraź sobie coś, czego nigdy nie widziateś, czyli nową konstrukcję. Obydwa byty wyobrażone mają swoje prezentacje w jaźni, czyli w kinie naszego mózgu, gdzie także integrowane są składowe percepcji, czyli sygnał zewnętrzny z pamięciowym przepisem, co z tym zrobić. A wszystko to $w$ zawiesinie emocjonalnego sosu nadającego smak.

Myślenie twórcze buduje nową konstrukcję z wiedzy i z tego, co twoja percepcja ledwie przeczuwa. Ten związek jest pre-konceptualny i musi użyć metafory ujmującej coś, co nie istnieje w porządku naszych pojęć. Wydaje się, że myślenie metaforyczne jest jedyną, a zarazem kluczową cechą wspólną nauki i sztuki.

Ponieważ zajmuję się bardziej sztuką niż nauką, powiem, jak to wygląda w sztuce.

Sztuka próbuje nazywać coś, co umysł dostrzega w przeżywaniu, ale na co nie ma konwencjonalnych wyrażeń (słów). Dlatego operuje metaforą, ujmuje to coś poprzez opis osobistego doznania, gdyż to coś nie ma swej słownikowej nazwy; sztuka odkrywa to przez nadanie temu czemuś postrzegalnej postaci w formule - JAKBY.

Artyści, tłumacząc swe dzieła, często używają słowa jakby. Choć słowo to ostatnio opanowała inteligencka maniera, nadal odnosi się ono do wyrażenia czegoś, co jest unikatowe i trudne do nazwania. Wydaje mi się, że JAKBY jest rodzajem kwantyfikatora języka sztuki. A jeśli tak jest, to metafora jest jedynym możliwym sposobem wyrażenia przeczucia i dlatego każda poprzedzona jest domyślnie stówkiem JAKBY. 